\title{
Zero Energy and Low Water Schools: Case Study- Building of Garaboulli Engineering Faculty-Libya
}

\author{
Salhin M. Alaud ${ }^{1 *}$, Khalid M. H. Jaballa ${ }^{2}$, Abdulghani M. Ramadan ${ }^{3}$ \\ ${ }^{1}$ Civil Department, Garaboulli Engineering Faculty, Elmergib University, Libya \\ ${ }^{2,3}$ Mechanical Department, Garaboulli Engineering Faculty, Elmergib University, Libya \\ DOI: https://doi.org/10.21467/proceedings.4.42 \\ * Corresponding author email: s.alaud@elmergib.edu.ly
}

\begin{abstract}
The current paper presents the design methodology for reducing the water consumption to reach a zero energy building. The building of the Garaboulli Engineering Faculty (GEF), Libya was chosen as a case study. The required energy will be supplied by renewable energy. In order to meet the required loads, solar energy is used in the design to generate heating, cooling, and electric power by using different techniques such as solar thermal collectors and photovoltaic panels. Moreover, rain water is used as a source of water supply for the building. To reach the low water and Zero Energy aims, different techniques such as recycling of greywater and solar cooling were adopted. Finally, the proposed system will be feasible for a long term of operation.
\end{abstract}

Keywords: Zero energy, Low water, Renewable energy, Rain water.

\section{Introduction}

The daily required of energy used increases continuously with a growing population. New buildings are constructed faster than old ones and thus increase the consumption of energy. On the other hand, the load on government supply of electricity or water increases over time. In the educational buildings, the increasing of consumption is depends on increase of student number.

Recently, water and power outages have increased as a result of increased demand of energy and water, and poor production capacity. From this perspective, alternatives ways are needed to find water and energy and ensure constant supply without interruption. Introducing of zero energy principle with rationing the water and energy uses into school buildings are particularly necessary when the supply of energy and water are intermittent. The zero energy is defined by the annual of the total energy amount used by the building that renewable energy sources. In general, a net zero energy is a building with highly reduced energy needs through efficiency gains such that the renewable technologies can supply the energy needs. In this paper, Garaboulli Engineering faculty building has designed to be low water consumption and zero energy building. Solar panels can generate the required amount of electricity that consumed by the faculty building every year.

(C) 2018 Copyright held by the author(s). Published by AIJR Publisher in Proceedings of First Conference for Engineering

Sciences and Technology (CEST-2018), September 25-27, 2018, vol. 2 .
This is an open access article under Creative Commons Attribution-NonCommercial 4.0 International (CC BY-NC 4.0) license, which permits any non-commercial use, distribution, adaptation, and reproduction in any medium, as long as the original work is properly cited. ISBN: 978-81-936820-6-7 
Zero Energy and Low Water Schools: Case Study-Building of Garaboulli Engineering Faculty-Libya

The large area of the building's roof allows collecting an ample amount of rainwater. Reuse of greywater for some purposes throughout the building will also save extra water.

\section{Description and Aims of the Project}

The building of Garaboulli Engineering Faculty is located at the north of the Garaboulli city on total area $17000 \mathrm{~m}^{2}$. The surface area of the main and attachment buildings is about 2100 $\mathrm{m}^{2}$. The green area is more than $2000 \mathrm{~m}^{2}$. The main building has four toilets with four sinks in each of six parts in two stories with total of 24 toilets and 24 sinks. A small kitchen is also including in the building. There are another toilet and kitchen in the gate building. The construction has 15 class rooms, 1 theatre, 2 electronic labs and 16 offices. Figure 1 illustrates the plan of the building and surrounded garden area. The project aims to benefit of the large surface area to generate the energy (electric, heating and cooling) from the solar and to collect the rain water to reduce the dependency on the general city network.
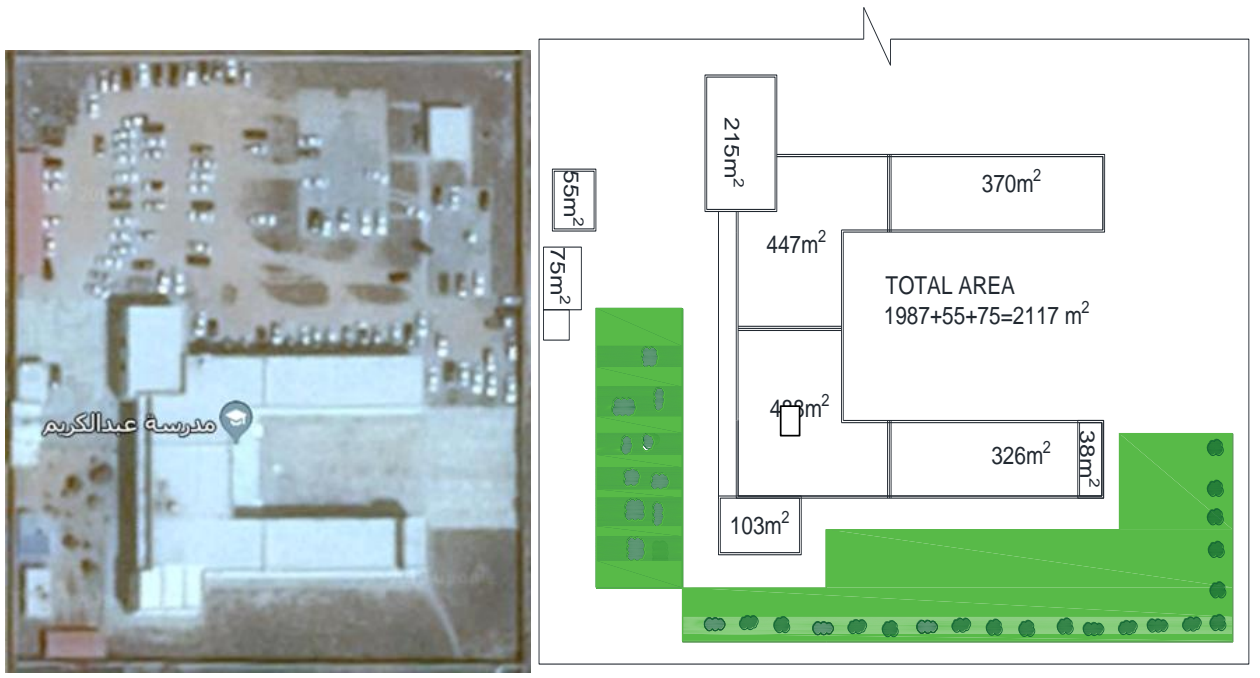

Figure 1: Garaboulli Engineering Building, Plan (left) and air photo (right)

\section{Design Methodology}

The current research attempts to find a suitable design to minimize the usage of water consumption from the city network by collecting the rain water and recycle the grey water or dispense on the network electricity by designing solar panels and heaters to generate the energy.

\subsection{Low Water}

Rainwater exploitation may not be sufficient to cover the total consumption of water, as this requires a very large area of water storage. Annual rainfall in some areas is also insufficient. The best ways are: rainwater exploitation to relieve the consumption from the public network, rationalize the consumption of water and recycling the grey water. 


\subsubsection{Rain Water Collection}

In general, Libya has a dry climate with intense rain storms and short in duration. Along the north of Libya, the rainfall months are from September to May, with most severe from October to January. The annual rainfall for Garaboulli city is taken a similar of the average of annual rainfall of the two nearest cities, Tajura and Tripoli, which have recorded data. The average of annual rainfall of these cities were similar in two different studies, $288 \mathrm{~mm} /$ year, where the results of Tajura was based on 40 years [1] and in Tripoli was based on 30 years of data [2]. The catchment area of the main building of the college $\left(2000 \mathrm{~m}^{2}\right)$ has considered. For the runoff, it is estimated that $15 \%$ of the rain water volume is released during the time required to fill the detention facility [1]. This is due to unavoidable any leakages or a possible overflow in the gutter downpipe system, or in the case of the downpour is too light to produce sufficient runoff. However, the total volume of detention facility is designed on $85 \%$ of the total rainwater collected as in Equation 1.

$$
q=0.85 \times 288 \times 2000=489.6 \times 10^{3} l / \text { year }=489.6 \mathrm{~m}^{3} / \text { year }
$$

\subsubsection{Water Consumption}

There are many studies and standards determine the varying amount of consumption in the universities and schools, such as 4.86-6.3 litters / student / day for secondary schools [3] and 125 - 180 // capita/day for Universities [4]. The large amount of the consumption at universities is due to use of larger this amount in laboratories, gardens and other facilities, while in the school case, the consumption only for drinking, washing and toilet flushing. The water consumption can be divided into:

1. Toilet flushing which make up about $30 \%$ of overall water consumption which produce the black water.

2. Wash basins, and floor cleaning that produces grey water as well as bidet faucets which mix with toilet sludge.

3. Water used to irrigate the garden.

4. Laboratory consumption such as concrete labs

Gray water can be recycled to use in the toilet flushing and irrigate the garden after a filtration and treatment process. Figure 2 illustrates the cycle of rain and city network water.

There are no reliable data for the water consumption in the target Faculty. Since the water consumption in the Faculty is limited to: $i$. washing; ii. toilet flushing; and iii. a small Garden, the consumption in our study for $\mathrm{i}$ and ii is estimated to be $6 / /$ capita/day. If we consider that the consumption rate is limited to school days only and the number of annual school days is 280 , the quantity required for annual consumption of water is $280 \times 6=1680 \mathrm{l} / \mathrm{capita} /$ year.

Proceedings of First Conference for Engineering Sciences and Technology (CEST-2018), vol. 2 


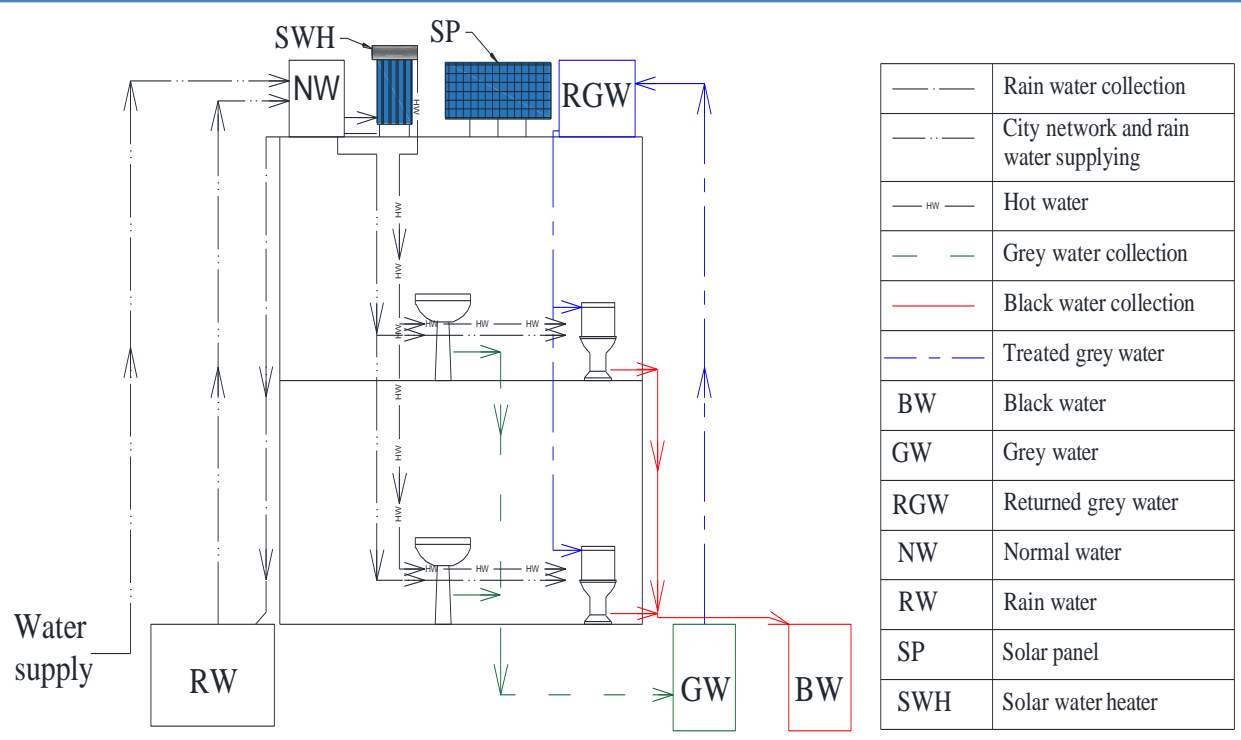

Figure 2: General section of water cycle

Assuming that the total daily number that can be presence in the college is a maximum of 700 people, thus, the annual consumption required is $700 \times 1680=1176 \times 10^{3} / /$ capita/year or 98 $\mathrm{m}^{3} /$ month. The use of grey water in the flushing will save about $30 \%$ of the consumption amount, thus, the needed consumption will be $68.6 \mathrm{~m}^{3} /$ month. The garden consumption (iii) is estimated to be $30 \mathrm{~m}^{3} /$ month, therefore, the monthly amount of water consumption is 98.6 $\mathrm{m}^{3} /$ month or say $100 \mathrm{~m}^{3} /$ month. Figure 3 illustrates the monthly average collected from rainwater [2] compared to the total monthly consumption as a percentage. The total rain water collected is $489 \mathrm{~m}^{3} /$ year and the total consumption requirement $1200 \mathrm{~m}^{3} /$ year, thus, the needed water from the city network is $711 \mathrm{~m}^{3} /$ year with save more than $40 \%$ of the consumption.

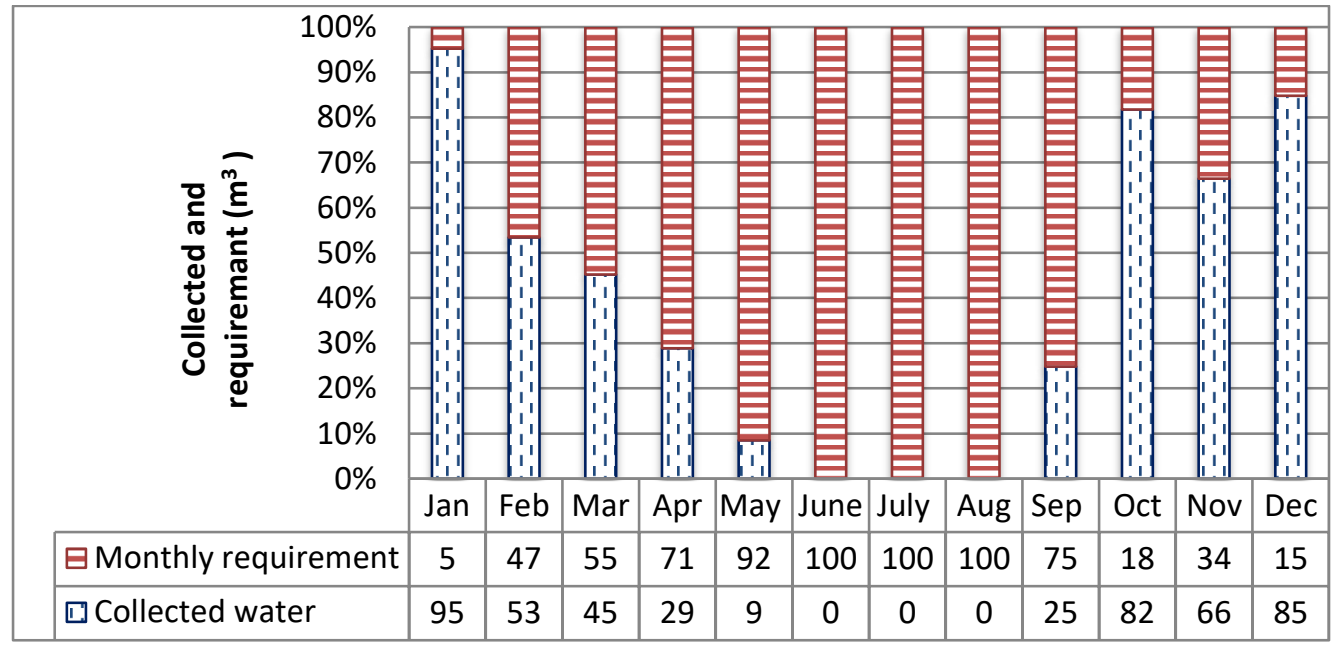

Figure 3: Collected water and monthly requirement 


\subsection{Cooling, Space Heating and SHW Loads}

In order to a achieve Net Zero Energy (NZE), Combi-system is the highest prospective technology which can offer that. A solar Combi-system is providing space heating, Service Hot Water (SHW) and cooling stock by solar collectors and an absorption cooling cycle. In this paper, for the purpose of designing a solar heating system, f-chart method and $\phi$ utilizability method are integrated together to merge the advantages and merits of the two methods to get more accurate and precise results[5],[6]. In order to start design process, relevant weather data required are shown in RetScreen software including local weather data, air temperature, latitude, tilt angle, daily solar radiation on horizontal surface...etc[8]. Moreover, Table 1 shows the input and design data for faculty of engineering at Garaboulli, includes the number of occupants, average daily service hot water consumption per capita in addition to other related data. In addition, Table 2 shows the proposed solar collector specifications. The first step in the design of solar thermal system is to determine the energy demand of the building by using RetScreen software, and assumption a faculty operation whole the year. Table 3 summarizes the different energy demands for the space heating, cooling, service hot water, and electric devises (Baseline energy) such as computers, lighting, surface pumps that calculated according to annual consumption of the faculty building. It should be noted that the total heating load requirement which covered by solar thermal system is calculated as following in Equation 2;

Total heating load $=$ heating for cooling + space heating load + SHW load

Total heating load $=3.65 \times 10^{12}(\mathrm{~J})$

Table 4: Input and design data for the faculty building

\begin{tabular}{|c|l|c|c|}
\hline S. No. & \multicolumn{1}{|c|}{ Item } & Value & unit \\
\hline 1 & Latitude & 32 & ${ }^{\circ} \mathrm{N}$ \\
\hline 2 & Tilt Angle & 42 & degree \\
\hline 3 & Number of Students & 700 & \\
\hline 4 & Average Service Hot Water Consumption & 2.3 & $\mathrm{~L} /$ day $/$ student \\
\hline 5 & Water Service Temperature & 60 & ${ }^{\circ} \mathrm{C}$ \\
\hline 6 & Water Density & 1000 & $\mathrm{~kg} / \mathrm{m}^{3}$ \\
\hline
\end{tabular}

Table 5: The proposed Solar Collector Specifications

\begin{tabular}{|c|l|c|c|}
\hline S. No. & \multicolumn{1}{|c|}{ Item } & Value & unit \\
\hline 1 & Type of Collector & Tubular & \\
\hline 2 & Gross Area of collector & 4.619 & $\mathrm{~m}^{2}$ \\
\hline 3 & $\left(\mathrm{~F}_{\mathrm{R}} \mathrm{U}_{\mathrm{L}}\right)$ & -1.26 & $\mathrm{~W} \mathrm{~m}^{-2}{ }^{\circ} \mathrm{C}^{-1}$ \\
\hline 4 & $\mathrm{~F}_{\mathrm{R}}(\tau \alpha)_{\mathrm{n}}$ & 0.51 & \\
\hline 5 & Collector Flow Rate & 0.566 & $\mathrm{~L} / \mathrm{s}$ \\
\hline 6 & Collector Fluid Specific Heat & 3600 & $\mathrm{~J} \mathrm{~kg}^{-1}{ }^{\circ} C^{-1}$ \\
\hline 7 & Collector Fluid Density & 1034 & $\mathrm{~kg} \mathrm{~m}^{-3}$ \\
\hline 8 & Heat Exchanger Effectiveness & 0.8 & \\
\hline 9 & Storage Tank Capacity & 1610 & Litre \\
\hline
\end{tabular}


Zero Energy and Low Water Schools: Case Study- Building of Garaboulli Engineering Faculty-Libya

Table 6: Energy demands for the faculty building

\begin{tabular}{|c|c|c|c|c|c|c|}
\hline Month & $\begin{array}{c}\text { Cooling } \\
\text { load } \\
\text { demand }(J)\end{array}$ & $\begin{array}{c}\text { Heating load } \\
\text { for cooling } \\
\text { demand }(J)\end{array}$ & $\begin{array}{c}\text { Heating } \\
\text { load }(J)\end{array}$ & $\begin{array}{c}\text { SHW } \\
(\mathrm{J})\end{array}$ & $\begin{array}{c}\text { Total heating } \\
\text { load }(J)\end{array}$ & $\begin{array}{c}\text { Electric } \\
\text { devices load } \\
(\mathrm{kWh})\end{array}$ \\
\hline Jan & 0.00 & 0.00 & $2.15 \times 10^{11}$ & $8.95 \times 10^{09}$ & $2.23 \times 10^{11}$ & $10,477.3$ \\
\hline Feb & $2.69 \times 10^{09}$ & $4.21 \times 10^{09}$ & $1.91 \times 10^{11}$ & $8.37 \times 10^{09}$ & $2.04 \times 10^{11}$ & $9,463.4$ \\
\hline Mar & $3.32 \times 10^{10}$ & $5.19 \times 10^{10}$ & $1.85 \times 10^{11}$ & $9.22 \times 10^{09}$ & $2.47 \times 10^{11}$ & $10,477.3$ \\
\hline Apr & $4.67 \times 10^{10}$ & $7.30 \times 10^{10}$ & $1.67 \times 10^{11}$ & $8.53 \times 10^{09}$ & $2.49 \times 10^{11}$ & $9,225.6$ \\
\hline May & $1.57 \times 10^{11}$ & $2.46 \times 10^{11}$ & $9.00 \times 10^{10}$ & $8.18 \times 10^{09}$ & $3.44 \times 10^{11}$ & $9,533.1$ \\
\hline Jun & $2.22 \times 10^{11}$ & $3.47 \times 10^{11}$ & $3.39 \times 10^{10}$ & $7.21 \times 10^{09}$ & $3.88 \times 10^{11}$ & $9,225.6$ \\
\hline Jul & $2.48 \times 10^{11}$ & $3.87 \times 10^{11}$ & $2.08 \times 10^{10}$ & $6.86 \times 10^{09}$ & $4.15 \times 10^{11}$ & $6,308.8$ \\
\hline Aug & $2.49 \times 10^{11}$ & $3.89 \times 10^{11}$ & $2.08 \times 10^{11}$ & $6.53 \times 10^{09}$ & $4.16 \times 10^{11}$ & $6,308.8$ \\
\hline Sep & $2.26 \times 10^{11}$ & $3.54 \times 10^{11}$ & $3.11 \times 10^{11}$ & $6.37 \times 10^{09}$ & $3.91 \times 10^{11}$ & $6,105.3$ \\
\hline Oct & $1.27 \times 10^{11}$ & $1.98 \times 10^{11}$ & $9.62 \times 10^{10}$ & $6.98 \times 10^{09}$ & $3.01 \times 10^{11}$ & $9,185.6$ \\
\hline Nov & $4.04 \times 10^{10}$ & $6.32 \times 10^{10}$ & $1.75 \times 10^{11}$ & $7.39 \times 10^{09}$ & $2.46 \times 10^{11}$ & $8,889.3$ \\
\hline Dec & 0.00 & 0.00 & $2.15 \times 10^{11}$ & $8.35 \times 10^{09}$ & $2.23 \times 10^{11}$ & $9,185.6$ \\
\hline Annual demand & $2.11 \times 1012$ & $1.44 \times 10^{11}$ & $9.29 \times 10^{10}$ & $3.65 \times 10^{12}$ & $104,386.40$ \\
\hline
\end{tabular}

Heating for cooling is defined as the heating energy which is required for absorption cooling system. It can be calculated as follows;

Heating for cooling $=$ cooling load demand $\mathrm{x}$ COP

In this study, the absorption cooling system COP is equal to 0.64 .

Next step, by using $\phi$-chart method, the number of collectors and the solar monthly energy

collected by collectors can be estimated with following Equation 3;

$$
Q=F_{R}(\overline{\tau \alpha}) \overline{H_{T}} \bar{\emptyset}
$$

Where is:

Q, the monthly energy collected by collectors $\left(\mathrm{J} / \mathrm{m}^{2}\right)$.

$\mathrm{F}_{\mathrm{R}}(\tau \alpha)_{\mathrm{n}}$, is readily determined from collector specifications.

$\mathrm{H}_{\mathrm{T}}$, is the monthly average daily radiation on tilted surface on the collector.

$\phi$, is the monthly average daily utilizability.

In order to calculate the required collectors' area in square meters and the available total annual solar energy $\left(\mathrm{J} / \mathrm{m}^{2}\right)$ in site. First, the solar radiation on tilted surface on collector in $\left(\mathrm{Kwh} / \mathrm{m}^{2}\right)$ should be calculated. Table 4 summarizes the estimated average monthly solar radiation on tilted surface on collectors. Furthermore, the monthly and annual solar thermal energy collected by collectors is also shown in Table 5. In view of the data shown in Tables 4 and 5, total annual solar thermal energy available $=3.49 \times 10^{09}\left(\mathrm{~J} / \mathrm{m}^{2}\right)$, and total annual thermal energy demand $=3.65 \times 10^{12}(\mathrm{~J})$, taken from Table 4 . Then, total collector area required is determined by Equation 4;

$$
\text { Total Collector Area Required }=\frac{\text { Total Annual thermal energy demand }}{\text { total annual solar thermal energy available }}
$$


Alaud et al., CEST-2018, AIJR Proceedings 4, pp.746-755, 2018

Table 7: The average monthly solar radiation on tilted surface on collectors

\begin{tabular}{|c|c|c|c|c|c|c|c|c|c|}
\hline \multirow{2}{*}{ Month } & $\overline{H_{o}}$ & $\bar{H}$ & $\mathrm{~K}_{\mathrm{T}}$ & $\mathrm{H}_{\mathrm{d}}$ & $\mathrm{H}_{\mathrm{b}}$ & $\mathrm{R}_{\mathrm{b}}$ & $\varrho_{\mathrm{g}}$ & $\overline{H_{T}}$ & $\overline{H_{T}}$ \\
\cline { 2 - 10 } & $\mathrm{x} 10^{7}$ & $\left(\mathrm{kWh} / \mathrm{m}^{2}\right)$ & $(-)$ & $\begin{array}{c}\left(\mathrm{J} / \mathrm{m}^{2}\right) \\
\mathrm{x} 10^{6}\end{array}$ & $\begin{array}{c}\left(\mathrm{J} / \mathrm{m}^{2}\right) \\
\mathrm{x} 10^{7}\end{array}$ & $(-)$ & $(-)$ & $\left(\mathrm{kWh} / \mathrm{m}^{2}\right)$ & $\begin{array}{c}\left(\mathrm{J} / \mathrm{m}^{2}\right) \\
\mathrm{x} 10^{7}\end{array}$ \\
\hline Jan & 1.99 & 2.9 & 0.53 & 3.83 & 0.661 & 1.90 & 0.2 & 4.50 & 1.62 \\
\hline Feb & 2.42 & 4 & 0.60 & 4.39 & 1.00 & 1.60 & 0.2 & 5.61 & 2.02 \\
\hline Mar & 3.06 & 5 & 0.59 & 6.28 & 1.17 & 1.24 & 0.2 & 5.67 & 2.04 \\
\hline Apr & 3.63 & 6 & 0.60 & 7.40 & 1.42 & 0.96 & 0.2 & 5.72 & 2.06 \\
\hline May & 4.00 & 6.5 & 0.58 & 8.23 & 1.52 & 0.78 & 0.2 & 5.43 & 1.96 \\
\hline Jun & 4.14 & 7 & 0.61 & 8.32 & 1.69 & 0.70 & 0.2 & 5.49 & 1.98 \\
\hline Jul & 4.07 & 7.1 & 0.63 & 8.02 & 1.75 & 0.73 & 0.2 & 5.69 & 2.05 \\
\hline Aug & 3.79 & 6.5 & 0.62 & 7.54 & 1.59 & 0.86 & 0.2 & 5.80 & 2.09 \\
\hline Sep & 3.30 & 5.5 & 0.60 & 6.69 & 1.31 & 1.10 & 0.2 & 5.76 & 2.07 \\
\hline Oct & 2.66 & 4 & 0.54 & 5.62 & 0.878 & 1.44 & 0.2 & 4.96 & 1.79 \\
\hline Nov & 2.12 & 3.1 & 0.53 & 4.08 & 0.708 & 1.79 & 0.2 & 4.59 & 1.65 \\
\hline Dec & 1.85 & 2.3 & 0.45 & 3.69 & 0.459 & 2.01 & 0.2 & 3.52 & 1.27 \\
\hline
\end{tabular}

Table 8: The monthly and annual solar thermal energy collected by collectors

\begin{tabular}{|l|c|l|l|l|l|l|l|l|l|l|l|l|}
\hline Month & $\begin{array}{c}\mathrm{H}_{\mathrm{T}} \\
\left(\mathrm{kWh} / \mathrm{m}^{2}\right)\end{array}$ & $\mathrm{R}$ & $\mathrm{a}$ & $\mathrm{B}$ & $\mathrm{r}_{\mathrm{t}, \mathrm{n}}$ & $\mathrm{r}_{\mathrm{d}, \mathrm{n}}$ & $\mathrm{R}_{\mathrm{n}}$ & $\mathrm{a}$ & $\mathrm{b}$ & $\mathrm{c}$ & $\varnothing$ & $\begin{array}{c}\mathrm{Q} \\
\left(\mathrm{J} / \mathrm{m}^{2}\right) \\
\mathrm{x} 10^{8}\end{array}$ \\
\hline Jan & 4.50 & 1.55 & 0.55 & 0.53 & 0.16 & 0.15 & 1.58 & -0.82 & -0.69 & 0.48 & 1 & 2.5 \\
\hline Feb & 5.61 & 1.40 & 0.59 & 0.49 & 0.16 & 0.14 & 1.42 & -1.15 & -0.35 & 0.69 & 1 & 2.8 \\
\hline Mar & 5.67 & 1.13 & 0.65 & 0.44 & 0.14 & 0.13 & 1.14 & -1.11 & -0.38 & 0.67 & 1 & 3.2 \\
\hline Apr & 5.72 & 0.95 & 0.70 & 0.38 & 0.13 & 0.12 & 0.96 & -1.15 & -0.35 & 0.69 & 1 & 3.14 \\
\hline May & 5.43 & 0.84 & 0.75 & 0.34 & 0.13 & 0.12 & 0.83 & -1.10 & -0.40 & 0.65 & 1 & 3.08 \\
\hline Jun & 5.49 & 0.78 & 0.77 & 0.32 & 0.12 & 0.11 & 0.78 & -1.21 & -0.29 & 0.73 & 1 & 3.01 \\
\hline Jul & 5.69 & 0.80 & 0.76 & 0.33 & 0.13 & 0.12 & 0.80 & -1.29 & -0.21 & 0.80 & 1 & 3.23 \\
\hline Aug & 5.80 & 0.89 & 0.72 & 0.36 & 0.13 & 0.12 & 0.89 & -1.25 & -0.25 & 0.76 & 1 & 3.29 \\
\hline Sep & 5.76 & 1.05 & 0.67 & 0.41 & 0.14 & 0.13 & 1.05 & -1.17 & -0.33 & 0.70 & 1 & 3.16 \\
\hline Oct & 4.96 & 1.24 & 0.61 & 0.47 & 0.15 & 0.14 & 1.26 & -0.89 & -0.61 & 0.52 & 1 & 2.81 \\
\hline Nov & 4.59 & 1.48 & 0.56 & 0.52 & 0.16 & 0.15 & 1.50 & -0.82 & -0.68 & 0.48 & 1 & 2.52 \\
\hline Dec & 3.52 & 1.53 & 0.53 & 0.54 & 0.17 & 0.16 & 1.56 & -0.40 & -1.11 & 0.28 & 1 & 1.99 \\
\hline
\end{tabular}

Proceedings of First Conference for Engineering Sciences and Technology (CEST-2018), vol. 2 752 
Zero Energy and Low Water Schools: Case Study- Building of Garaboulli Engineering Faculty-Libya

Total Collector Area Required $\left.=3.65 \times 10^{12}(\mathrm{~J}) / 3.49 \times 10^{09} \mathrm{~J} / \mathrm{m}^{2}\right)=1046\left(\mathrm{~m}^{2}\right)$

The number of collectors required is calculated by Equation 5;

$$
\text { Number of collectors needed }=\frac{\text { Total Collector Area required }}{\text { Area of single collector }}
$$

Number of collectors needed $=(1046 / 4.619)=226.4$ collectors approx. 227 collectors .

After that, the estimated solar fraction which is defined as the percentage of the energy requirements that can be met by a solar energy system. It is calculated by f-Chart method. Table 6 shows the energy met by the solar system and solar fraction. The solar collector combisystem proposed is collector type Tubular - with model SEIDO5-16 AS/AB and tilt angle of $42^{\circ}$ with horizontal surface. The working fluid used in this collector is anti-freezing with water solution. For cooling, the absorption cycle is used to cover the cooling load with COP 0.64. All the process of working fluid inside the system between the hot region and cold region are controlled by sophisticated computerized system [7].

Table 9: Energy met by the solar collector and the value of solar fraction

\begin{tabular}{|c|c|c|c|c|c|c|c|c|}
\hline Month & $\begin{array}{l}\text { Total Heating } \\
\text { Energy demand } \\
(\mathrm{J} / \mathrm{month}) \times 10^{11}\end{array}$ & $\begin{array}{l}\text { second } \\
\text { per } \\
\text { month }\end{array}$ & $\frac{(\bar{\tau} \bar{\alpha})}{(\bar{\tau} \bar{\alpha})_{n}}$ & X (-) & $\mathrm{Y}(-)$ & $\mathrm{f}(-)$ & $\begin{array}{c}\mathrm{f} \\
\text { actual } \\
(-)\end{array}$ & $\begin{array}{l}\text { Energy } \\
\text { met by } \\
\text { collector } \\
\text { (J) } \times 10^{11}\end{array}$ \\
\hline Jan. & 2.23 & 2678400 & 0.96 & -3.686 & 1.145 & 1.154 & 1.00 & 2.23 \\
\hline Feb. & 2.03 & 2419200 & 0.96 & -3.618 & 1.418 & 1.286 & 1.00 & 2.03 \\
\hline Mar. & 2.46 & 2678400 & 0.96 & -3.200 & 1.310 & 1.202 & 1.00 & 2.46 \\
\hline Apr. & 2.48 & 2592000 & 0.9 & -2.941 & 1.187 & 1.119 & 1.00 & 2.48 \\
\hline May & 3.43 & 2678400 & 0.9 & -2.087 & 0.844 & 0.850 & 0.85 & 2.92 \\
\hline Jun. & 3.87 & 2592000 & 0.9 & -1.709 & 0.732 & 0.747 & 0.75 & 2.89 \\
\hline Jul. & 4.14 & 2678400 & 0.9 & -1.614 & 0.732 & 0.740 & 0.74 & 3.07 \\
\hline Aug. & 4.16 & 2678400 & 0.9 & -1.597 & 0.745 & 0.748 & 0.75 & 3.11 \\
\hline Sep. & 3.91 & 2592000 & 0.9 & -1.687 & 0.760 & 0.765 & 0.76 & 2.99 \\
\hline Oct. & 3.01 & 2678400 & 0.96 & -2.380 & 0.939 & 0.933 & 0.93 & 2.80 \\
\hline Nov. & 2.45 & 2592000 & 0.96 & -3.029 & 1.029 & 1.036 & 1.00 & 2.45 \\
\hline Dec. & 2.22 & 2678400 & 0.96 & -3.642 & 0.898 & 1.003 & 1.00 & 2.22 \\
\hline Total & 36.5 & \multicolumn{5}{|c|}{ Annual solar fraction } & 0.87 & 31.7 \\
\hline
\end{tabular}

\subsection{Photovoltaic System Design}

The Photovoltaic system is used to cover the electrical power demand for the faculty building. Two cases are considered; On-Grid design and off-Grid design. Table 7 shows the specification of module used to produce the electric power $(\mathrm{kWh})$ [8].

By using PVwatts program, the monthly power production output ( $\mathrm{kWh} / \mathrm{month}$ ) can be estimated as shown in Table 8. It gives the monthly power production under the conditions; tilt angle $42^{\circ}$, the module face on south direction, and assuming $15 \%$ losses due to shadow, wiring and dust. It should be noted that the net total electric energy needed and sent to Grid is zero. In this sense, the electric design is net zero energy class. 
Alaud et al., CEST-2018, AIJR Proceedings 4, pp.746-755, 2018

Table 10: Energy met by the PV system with specifications of PV module used

\begin{tabular}{|l|c|l|}
\hline Design PV System & \multicolumn{2}{|l|}{} \\
\hline Efficiency of the inverter & 0.9 & AC to DC \\
\hline Voltage DC system & 49 & volte \\
\hline Peak Amp for module & 7.86 & \\
\hline Peak sun hours & 4 & hr/day \\
\hline Design module system & Mono-silicon module \\
\hline Type of Module & Grape Solar & Gs-S-385-TS \\
\hline Power of module $(\mathrm{W})$ & 385 & Watt \\
\hline Area of a module $m^{2}$ & 2.56 & $m^{2}$ \\
\hline Nominal voltage for module & 49 & Volte \\
\hline
\end{tabular}

Table 11: Electric energy demand and $P V$ power production On -Grid output data

\begin{tabular}{|c|c|c|c|c|c|c|}
\hline Month & $\begin{array}{c}\text { Heating } \\
\text { demand still } \\
\text { not covered } \\
\mathrm{kWh}\end{array}$ & $\begin{array}{c}\text { Electric } \\
\text { device } \\
\text { demand } \\
\mathrm{kWh}\end{array}$ & $\begin{array}{c}\text { electric } \\
\text { demand from } \\
\text { PV system } \\
\mathrm{kWh}\end{array}$ & $\begin{array}{c}\text { PV system } \\
\text { Production } \\
\mathrm{kWh}\end{array}$ & $\begin{array}{c}\text { Need } \\
\text { from grid } \\
\mathrm{kWh}\end{array}$ & $\begin{array}{c}\text { Send to } \\
\text { grid } \\
\mathrm{kWh}\end{array}$ \\
\hline Jan. & 0.0 & $10,477.38$ & $10,477.38$ & 9,335 & -1142.38 & 0 \\
\hline Feb. & 0.0 & $9,463.44$ & $9,463.44$ & 9,385 & -78.44 & 0 \\
\hline Mar. & 0.0 & $10,477.38$ & $10,477.38$ & 11,716 & 0 & 1238.62 \\
\hline Apr. & 0.0 & $9,225.6$ & $9,225.6$ & 11,985 & 0 & 2759.4 \\
\hline May & $4,434.8$ & $9,533.12$ & $13,967.87$ & 11,872 & -2095.87 & 0 \\
\hline Jun. & $5,415.7$ & $9,225.6$ & $14,641.29$ & 11,894 & -2747.29 & 0 \\
\hline Jul. & $5,950.1$ & $6,308.88$ & $12,258.97$ & 12,878 & 0 & 619.02 \\
\hline Aug. & $5,789.0$ & $6,308.88$ & $12,097.87$ & 13,284 & 0 & 1186.12 \\
\hline Sep. & $5,071.5$ & $6,105.37$ & $11,176.84$ & 11,968 & 0 & 791.15 \\
\hline Oct. & $1,112.5$ & $9,185.68$ & $10,298.22$ & 10,698 & 0 & 399.77 \\
\hline Nov. & 0.0 & $8,889.37$ & $8,889.37$ & 8,922 & 0 & 32.628 \\
\hline Dec. & 0.0 & $9,185.68$ & $9,185.68$ & 8,223 & -962.68 & 0 \\
\hline & & Total & $132,159.95$ & $132,160.00$ & -7027 & 7027 \\
\hline
\end{tabular}

In order to calculate the number of modules and total area meter square needed to cover the electric load, PVwatts program is used. The size of capacity for PV modules is ( $87.5 \mathrm{~kW})$. Then, total number of PV modules can be calculated from Equations 6 and 7;

Size DC $(K W)=$ Module Capacity $\times$ No. of Modules

Thus, $\quad$ No. of Modules $=\frac{87.5 \times 1000}{385}=227.27=$ approx 228 module

The total area for PV modules $=$ No. of modules $x$ Area of module

$$
=228 \times 2.56=583.68 \mathrm{~m}^{2}
$$


Zero Energy and Low Water Schools: Case Study-Building of Garaboulli Engineering Faculty-Libya

Another method for design PV system called stand-alone system (off-grid system) in which the system is working without any auxiliary source or supply for electricity such as grid [9]. Stand-alone system use batteries to store a power replacing the grid, Table 9 show the specification of batteries. It should be noted that the total number of batteries used for the PV system in this study is 715 batteries with number of modules 426 covered $1091.61 \mathrm{~m}^{2}$.

Table 12: Specifications of the batteries for the stand-alone PV system

\begin{tabular}{|l|c|l|}
\hline \multicolumn{2}{|l|}{ PV system for Stand-alone system } & Unit \\
\hline Discharge limit & 0.75 & \\
\hline Battery current Amp.hours & 300 & Ah/day \\
\hline Battery Voltage & 12 & Volt \\
\hline Efficiency of battery & 0.8 & \\
\hline Anatomy days & 3 & Days \\
\hline
\end{tabular}

\section{Conclusions}

In this paper, the low and zero energy building design principles are applied to the faculty of engineering building at Garaboulli-Libya. Collected rain water and recycled grey water quantities are designed to be used for drinking, washing and toilet flushing or irrigation. The cooling, space heating and service hot water demand is determined. In addition, the total number and the area of the solar collectors are also evaluated. The electric demand for the building is also determined. Two design scenarios for covering electrical demands are adopted; Off-Grid and On-Grid. Total number of PV modules and total area are also calculated. Results show that the net zero energy design could be applicable for space heating, cooling and electricity demand. However, low energy design principle could be the case of rain water and grey water demand since the quantities are not sufficient to meet the required water demand. Finally, the issue of insulation, walls material, shading and other architectural measures are not taken into considerations in this study.

\section{References}

[1] Housing and Infrastructure Board, "Guidance Document," Program Management Department, Tajura, Libya, 2008.

[2] A. M. Ramadan, "Design Methodology and Maintenance Strategy of a Solar Gradient Solar Pond Coupled with an Evaporation Pond," M.Sc thesis, Tripoli University, Tripoli, Libya, 1999.

[3] A. M. Shuraideh, "Water consumption Practices in Schools of Nablus directorate of Education," M.Sc theses, Nablus: An-najah National University, 2015.

[4] J. Zhang, "University of California Berkeley Water Usage and Conservation," Study Report, Chancellor's Advisory Committee on Sustainability, California, 2010.

[5] F-Chart Active and Passive Solar Systems Analysis, online in 2008 at https:// www.fchart.com/fchart/fchart.shtm

[6] I. F. Okafor and G. Akubue, "F-Chart Method for Designing Solar Thermal Water Heating Systems," International Journal of Scientific \& Engineering Research, Volume 3, Issue 9, September 2012, ISSN 2229-5518

[7] C. Webera, M. Bergerb, F. Mehlinga, A. Heinricha, T. Núñeza1, "Solar Cooling with Water-ammonia Absorption Chillers and Concentrating Solar Collector - Operational Experience," International Journal of Refrigeration ,Volume 39, Pages 57-76, March 2014

RET Screen International webpage, online in 2018 at http://www.retscreen.net

[8] Jin-Hee Kim, Ha-Ryeon Kim, and Jun-Tae Kim, "Analysis of Photovoltaic Applications in Zero Energy Building Cases of IEA SHC/EBC [9] Task 40/Annex 52," Sustainability 2015, 7, 8782-8800; doi:10.3390/su7078782, 2015 